\title{
CORPORATE TAXATION: CORPORATION NOT COLLAPSIBLE IF VIEW TO SELL ARISES AFTER COMPLETION OF CONSTRUCTION
}

$\mathrm{S}_{\text {ECrion 34I }}$ of the Internal Revenue Code ${ }^{1}$ provides that gain from the sale or exchange of stock in a "collapsible corporation" is to be taxed as ordinary income rather than as capital gain. ${ }^{2}$ The statute defines a collapsible corporation as "a corporation formed or availed of principally ${ }^{3}$ for the manufacture, construction, or production of property ... with a view to the sale or exchange of stock by its shareholders (whether in liquidation or otherwise), or a distribution to its share-

"The "collapsible corporation" provision was enacted in x950: Int. Rev. Code of 1939, § I 17 (m) added by ch. 994, 64 Stat. 906 (now INT. REv. CoDe OF 1 954, § 34 I).

"The tax advantages originally enjoyed by the use of the "collapsible corporation" and the congressional purpose in enacting corrective legislation are set out in the following Senate report:

"The collapsible corporation is a device which has been used in an attempt to convert ordinary income into long-term capital gain by use of a temporary corporation. The device has been used principally in the motion picture industry. A legitimate corposation engaged in the businesss of producing motion pictures would ordinarily pay the corporate income tax on its net income and its shareholders would pay ordinary income tax on their dividends from the corporation. Producers have tried to avoid these results by organizing separate corporations for each motion picture. Upon completion of the film but prior to the realization by the corporation of any income therefrom, the corporation is liquidated and the assets are distributed. In such a case, the corporation pays no tax, claiming that it has realized no income. The producer pays tax upon the difference between his cost and the fair market value of the assets so distributed; but such gain is reported as long-term capital gain with a maximum effective rate of 2.5 percent. After liquidation, the fair market value of the released production is ordinarily amortized against the income from the film as it is received. If the income from the film does not exceed such fair market value, there is no further tax.

"In addition to the motion-picture industry, it is understood that the collapsiblecorporation device has also been used in the building-construction trade by contractors who have corporations construct buildings for sale and then liquidate the corporation and sell the buildings as individuals.

"Under section $21_{3}$ of your committee's bill the gain realized from the sale or exchange (including liquidation) of stock in a collapsible corporation will be treated as ordinary income for tax purposes ...." S. REP. No. 2375, 8rst Cong, 2d Sess. 45 (1950). The identical report is contained in H.R. REP. No. 2319, 81 st Cong., 2d Sess. 56 (1950).

"The Courts have held that "principally" modifies "manufacture, construction, or production of property," rather than "with a view to." Burge v. Commissioner, 253 F.2d 765, 768 (4th Cir. 1958), Weil v. Commissioner, 252 F.2d 805, 806 (2d Cir. $1958)$. 
holders, prior to the realization ... of a substantial part of the net income to be derived from such property ...." A frequent problem that arises in determining whether a corporation is "collapsible" is the interpretation of the phrase "with'a view to."

In the recent case of Jacobson v.'Commissioner ${ }^{5}$ the Court of Appeals for the Third Circuit held that a corporation formed to construct a housing project was not collapsible since the petitioners' ${ }^{\text {' }}$ intent to sell their stock arose only after completion of construction and the circumstances that led to the sale of the stock were not within their reasonable contemplation before construction had been completed. Thus, the gain realized from the sale of stock was held to be taxable as capital gain rather than as ordinary income. In so holding, the court adopted a much more favorable attitude toward the taxpayer than that presently held by other courts of appeals and the Tax Court.

The petitioners in Jacobson formed Hudson Towers, Inc., for the construction of five apartment buildings. A short time after completion of construction, a small crack was discovered in one of the buildings. Fearful that the buildings might develop additional and more extensive cracks, petitioners sold their stock in the corporation. The Commissioner, determining that Hudson Towers was a collapsible corporation, held that the gain from the sale of stock was taxable as ordinary income.

On appeal to the Tax Court, ${ }^{7}$ petitioners claimed that the corporation had been formed for long-term investment purposes and that the sale of stock resulted solely from an unanticipated defect in one of the buildings which made the petitioners fearful of the security of their investment. They argued that the corporation was not collapsible since

"INT. REV. CODE OF 1954, § 341 (b) (1). For general treatments of the "collapsible corporation," see: Bittker, The Tax Treatment of Collapsible Corporations, I3 VAND. L. REv. 129 (1959); Donaldson, Collapsible Corporations, 36 TAXES 777 (1958); Seidman, Collapsible Corporations-Applicable to Real Estate Transactions, 15 TAX L. Rev. 12x (1959); Collapsible Corporations: A Sympositum on What is and What Is Not Collapsible, 22 J. TAXaTion 194 (1960); Note, Collapsible Corporations: An Analysis of the Past, Present, and Proposed Collapsible Concepts, 28 Geo. WASH. T. REV. 855 (1960).

281 F.2d ,703 (3d Cir. 1960). Jacobson involved an interpretation of $\$ 117$ (m) (2) (A) of the 1939 Internal Revenue Code. Because this section of the 1939 Code is substantially identical to $\S 34 \mathrm{r}(\mathrm{b})$ (r) of the 1954 Code, in discussing Jacobson reference will bè made to $\$ 341$ (b) ( 1 ).

"In determining whether the requisite "view" is present, the persons whose "view" governs are "those persons in a position to determine the policies of the corporation whether by reason of their owning a majority of the voting stock of the corporation or otherwise." Treas. Reg. \& 1.341-2(a) (2) (1955).

${ }^{7} 32$ T.C. 893 (1959). 
it had not been formed with the requisite statutory intent or "view to" sale, which they contended had to be formed not later than at the time of completion of construction. In support of their position, the petitioners cited the following Treasury Regulation: ${ }^{8}$

[I]f the sale, exchange, or distribution is attributable solely to circumstances which arose after the manufacture, construction, production, or purchase (other than circumstances which reasonably could be anticipated at the time of such manufacture, construction, production or purchase), the corporation shall, in the absence of compelling facts to the contrary, be considered not to have been so formed or availed of.

The Tax Court affirmed the Commissioner's decision, finding that the requisite "view" existed prior to the completion of construction." Thus, the court held that the corporation was collapsible as defined by the Regulations. The court further remarked that the Regulations might be unduly favorable to the petitioner and that, possibly, even if the "view" arose after completion of construction, the corporation might still be collapsible.

Other courts also have questioned the position of the Treasury as to when the requisite "view" must be formed. Dicta in cases from the Courts of Appeals for the Second ${ }^{10}$ and Fourth ${ }^{11}$ Circuits suggest that section $34 \mathrm{I}(\mathrm{b})(\mathrm{r})$ should be construed so that the phrase "with a view to" modifies the phrase "formed or availed of," and not the phrase "manufacture, construction, or production of property." Under this construction, the requisite view might exist at any time the corporation is "availed of" for the purpose of enabling the shareholders to realize gain attributable to the manufacture, construction or production of property

\footnotetext{
${ }^{8}$ Treas. Reg. $\$$ 1.341-2(a)(3) (1955). For examples of when the "view" is not present, see Treas. Reg. $§ 1.24$ I-5 (d) (3) (1955) (corporation" not collapsible when sale of stock due to sudden and unexpected illness); Rev. Rul. 57-575, 1957-2 Cum. BuLL. ${ }_{23} 6$ (corporation not collapsible when sale of stock due to legislation passed subsequent to completion of construction).

'The court held that the petitioners' argument that the "view to sell" arose only after the defect had been discovered was supported only by the self-serving testimony of the petitioners and was "unconvincing." The court stated: "If the initial intent of long-term investment was as strong and persistent as petitioners contend, we think it unlikely and improbable that it gave way to fears arising from what appears to have been an insubstantial crack in one of the five apartment buildings." The court also attached significance to the fact that the petitioners had not consulted an architect $o r$ engineer concerning the possibility of future defects developing in the buildings, but had relied almost exclusively on the fears of one of the shareholders.

${ }^{10}$ Glickman v. Commissioner, 256 F.2d 108 (2d Cir. 1958).

${ }^{11}$ Burge v. Commissioner, 253 F.2d 765 (4th Cir. 1958 ).
} 
before the corporation itself had realized a substantial part of the net income to be derived from the property. Therefore, subject only to the limitations prescribed in the statute, ${ }^{12}$ the requisite view might be formed after the construction had been completed or at any other time during the corporate existence. ${ }^{\mathbf{1 3}}$

Thus, in Jacobson the Court of Appeals was confronted with two different positions as to when the statutory view must be formed for a corporation to be collapsible. The court adopted the position of the Regulations. In rejecting the interpretations expounded by the Second and Fourth Circuits, the court said: ${ }^{14}$

On the face of the statute Congress is here indicating a state of mind which must attend and give significance to certain action. That action ... is not merely any formation or use of a corporation but rather the formation or use of a corporation to construct or produce property. The "view" with which a corporation is used for a particular purpose must necessarily be a view entertained at the time of such use. Thus, only by a distorting disregard of the phrase "for the ... construction ... of property" is it possible to reach the conclusion that the "view to ... sale" contemplated by the statute can arise for the first time in connection with corporate activity after the work of construction is completed.

It would appear that the interpretation given the phrase "with a view to" by the court in this case is sounder than that of the Second and Fourth Circuits. It is true that the latter interpretation would ease the administration of the statute by alleviating the necessity of finding the time at which the requisite "view" existed. However, such an

\footnotetext{
${ }^{19}$ See INT. REV. CODE OF $1954, \$ 341(\mathrm{~d})$ and $\$ 34 \mathrm{I}(\mathrm{e})$.

${ }^{13}$ In Glickman v. Commissioner, 256 F.2d 108, 111 (2d Cir. 1959), the court in criticizing the narrow scope given the statute by the Treasury, said:

"Since the corporation may at any time during its corporate life be 'availed of' for the proscribed purpose ... it seems surprising that the Regulations have adopted a narrower interpretation of the statute, and require the requisite view to exist 'during the construction ...' or to be 'attributable' to 'circumstances which reasonably could be anticipated by the time of such ... construction.' We are disposed to disagree with so narrow an interpretation."

The position of Burge, 253 F.2d 765 (4th Cir. 1958), and Glickman, supra, was questioned in Payne v. Commissioner, 268 F.2d 617 (5th Cir. 1959), in which the court said at 620:

"While not disagreeing with this construction of the statute, we recognize that it scems to overlook the requirement by the statute that the corporation must be availcd of for construction of property with a view to a distribution, etc. A respectable argument can be made that this means that unless the 'view' is held before or during construction, the statute is not satisfied."

${ }^{14} 281$ F.2d at 705 .
} 
interpretation would virtually abolish the subjective test that Congress intended to be applied and would render meaningless the phrase "with a view to."

Applying its interpretation of the statute to the facts in Jacobson, the court held that the evidence was sufficient to support the conclusion that the "view to sell" did not arise until after completion of construction and that the circumstances that led to the sale were not within reasonable contemplation before construction was completed. Therefore, Hudson Towers, Inc., was not a collapsible corporation. This finding that the requisite view did not exist prior to the completion of construction was based primarily upon the following facts: (I) After construction had been completed, a real estate broker who on two occasions sought authority to sell the apartment houses was told that the property was not for sale; (2) the petitioners had made other long-term investments in rental property; (3) none of the petitioners was in the business of constructing and selling apartment houses or any other kind of real estate; (4) since the apartments had been constructed on ground on which it had been necessary to deposit fill, it was natural for the petitioners to fear that further and more extensive cracks might develop; and (5) a majority of the petitioners originally did not wish to sell even after the cracks had been discovered and after one of the petitioners had recommended sale.

Prior to Jacobson, taxpayers had met with little success in attempting to prove that their "view to sell" arose after completion of construction. Courts found either that the "view" arose while construction was still in progress or that the circumstances causing the sale or distribution were actually anticipated or reasonably could have been anticipated. ${ }^{15}$ Since taxpayers often have misused the corporate entity by

\footnotetext{
${ }^{15}$ In attempting to prove that their "view" to sale or distribution arose after completion of construction, other taxpayers have unsuccessfully argued that: ( $\mathrm{I}$ ) The plan to distribute excess mortgage funds was formed after the construction was completed, upon the advice of the petitioners' accountants. Jesse Hartman, P-H Tax Ct. Rep. \& Mem. Dec. I 34.1 I (Sept. 22, 1960); appeal docketed, No. 65826, 2d Cir., Dec. I 5, 1960. (2) Due to strike possibilities and uncertain cost, it was impossible until after the completion of construction to know that mortgage proceeds would exceed the cost of construction. Rose Sidney, 30 T.C. II55 (1958). (3) There was a distribution of surplus mortgage funds and a redemption of stock one year after completion of construction when the need for funds or another project became urgent. Elizabeth $M$. August, 30 T.C. 969 (1958). (4) There was a sale of stock because of disagreement among shareholders. Max Mintz, 32 T.C. 723 (1958). (5) Stock was sold to avoid undesirable competition, to secure common equipment and janitor service, and to avoid management problems. Carl B. Rechner, 30 T.C. I86 (1958). (6) The
} 
forming temporary corporations and then selling or liquidating in order to take advantage of capital gain rates, it is not unexpected that the courts should be reluctant to accept the taxpayers' contention of a postconstruction "view to sell." Also, that such contentions are usually supported primarily by the self-serving testimony of the taxpayer undoubtedly has been a factor in the courts' skepticism. In light of this judicial attitude, it is somewhat surprising that the petitioners prevailed in Jacobson, particularly when there were facts from which it reasonably could be concluded that the "view to sell" was not prompted by the discovery of a crack in one of the buildings. ${ }^{16}$

It is inevitable that attempts to interpret and apply a subjective standard found in an ambiguous statute will be characterized by disagreement and confusion. Perhaps the most feasible solution to the problems involved in determining whether a corporation is collapsible would be to abolish the subjective test. The Advisory Group appointed in 1956 to assist the House Ways and Means Committee in its study of subchapter $\mathrm{C}$ of the 1954 Code substituted an objective, and mathematical test of collapsibility for the present subjective test. ${ }^{17}$ A corporation would be "collapsible" if the unrealized appreciation of non-capital assets were "more than fifteen percent of the amount by which the fair market value of all its assets exceeds all its liabilities, and more than

sale of stock was made only after the housing project proved to be a disappointing financial failure. Raymond G. Burge, 28 T.C. 246 (1957). But see Coates v. United States, P-H 1960 Fed. Tax. Serv. (6 Am. Fed. Tax. R.zd 5200) I60-5065 (D.C. Ore. May 17,1960 ), in which the jury found that three corporations engaged in building apartment houses were not collapsible corporations.

${ }^{10}$ On appeal to the Court of Appeals, the Commissioner contended that the building defect was minor and did not motivate the sale, pointing out that: ( 1 ) a crack was discovered in only one out of the five buildings; (2) the crack extended to only about three or four bricks; (3) the salesman who was employed by the petitioners to sell the buildings and who was familiar with the buildings had previously testified that he did not learn of the crack until the time of the Tax Court hearing; (4) there was no evidence that the mortgagee of the F.H.A. who insured the mortgage was informed of the discovery of the crack, although in the commitment for insurance there was a requirement that any change in the condition of the buildings upon which the insurance was given had to be reported to the F.H.A.; (5) the building was still standing in January, 1959, approximately eight and one-half years after the discovery of 'the crack; and (6) even though there was an investment of $\$ 1,800,000$ in the buildings, petitioners made no thorough investigation of the seriousness of the crack.

${ }^{17}$ The Advisory Group's proposals appear in section 343 of H.R. REP. No. 4459, 86th Cong., Ist Sess. 43-52 (1959). For au excellent discussion of the Advisory Group's recommendations, see Note, Collapsible Corporations: An Analysis of the Past, Present, and Proposed Collapsible Concepts, 28 GEo. WAsH. L. Rev. 855 (1960). 
fifteen percent of the unrealized appreciation on all its assets." ${ }^{\text {"18 }}$. Under this test the motive of the taxpayer in forming the corporation would be of no importance in determining whether the corporation is collapsible. Removal of the uncertainty and confusion embodied in the subjective phrase "with a view to" seems of sufficient worth to more than balance any injustice that might occasionally result from the adoption of an arbitrary objective standard. ${ }^{10}$

\footnotetext{
${ }^{18}$ H.R. REP. No. 4459, 86th Cong,, Ist Sess. 5 I (1959). An objective standard has been advocated by many legal writers. See, e.g., MacLean, Collapsible Corporations -The Statute and Regulations, 67 HARv. L. REv. 55 (1953).

${ }^{10}$ The proposed objective test, however, also would raise new problems, for example, the difficulty in valuing corporate assets. See Note, Collapsible Corporations: $A n$ Analysis of the Past, Present, and Proposed Collapsible Concepts, supra note 17, at 884 .
} 